\begin{tabular}{l|l|l} 
Jurnal Eksplorasi Akuntansi & $\begin{array}{l}\text { ISSN : 2656-3649 (Online) } \\
\text { hol. 2, No 1, Seri D, Februari 2020, Hal 2407-2427//jea.ppj.unp.ac.id/index.php/jea/issue/view/20 }\end{array}$
\end{tabular}

\title{
PENGARUH USIA DAN RELIGIUSITAS TERHADAP KEYAKINAN ETIS PADA AKUNTAN
}

\author{
Azhari Pratama ${ }^{1}$, Herlina Helmy ${ }^{2}$, Mayar Afriyenti ${ }^{3}$ \\ ${ }^{1}$ Alumni Jurusan Akuntansi Fakultas Ekonomi, Universitas Negeri Padang \\ 2,3Jurusan Akuntansi Fakultas Ekonomi, Universitas Negeri Padang \\ *Korespondensi: pratama.azhari@yahoo.co.id
}

\begin{abstract}
This research aims to determine the effect of age and religiosity on accounting student this study also one to prove the differences the ethical beliefs between the beginning level of student. The sample selection in this study used a purposive sampling method. The population this study are where the accounting student all the university in Padang with is consisted of 3249 population. Respondents in this study consisted of 356 respondents obtained using the Slovin formula from the total population. Data collection techniques used in this study were questionnaires. The result should that age also proves effect on ethical beliefs in accountants with a tcount of $3.739<$ ttable 1.960, it can be said that the first hypothesis was accepted. While the results of religiosity testing are known not to have a positive effect on the ethical beliefs of accountants. With the value of tcount -4,900> ttable 1,960 so it can be said that the second hypothesis is rejected. From the result of data processing it is also known that there are differences in ethical beliefs between beginning level students and final level students. This research also proves the concept theory moral cognitive Kohlberg.
\end{abstract}

Keywords: Age, Religiosity, Ethical Beliefs, Beginning Student College, Final Student College, Accounting, Ethics

How to Cite (APA $6^{\text {th }}$ style)::

Pratama, Azhari; Helmy, Herlina \& Afriyenti, Mayar. (2020). Pengaruh Usia dan Religiusitas Terhadap Keyakinan Etis Pada Akuntan. Jurnal Eksplorasi Akuntansi, 2(1), Seri D, 2407-2427.

\section{PENDAHULUAN}

Kemajuan bisnis yang sangat cepat pada era sekarang ini banyak memunculkan bermacam kejadian ataupun kasus bisnis yang banyak melibatkan profesi akuntan. Diantara kasus ataupun kejadian yang ada professional dari seorang akuntan dipertanyakan dikarenakan banyak dari akuntan melanggar serta tidak mematuhi kode etik profesi yang telah dibuat. Diantaranya adalah kasus etika, dimana Keyakinan etis para akuntan dalam membuat keputusan menjadi sebuah ancaman untuk keberlangsungan profesinya (Fadli, 2014).

Di negara Indonesia, kasus pelanggaran etika sangat banyak terjadi seiring dengan banyaknya profesi dari kantor akuntan publik yang membuka usaha konsultasi di Indonesia itu sendiri, baik konsultan publik lokal ataupun konsultan publik yang berafiliasi dengan pihak asing 
(Ludigo, 2010). Hampir semua akuntan publik menyadari bahwa keyakinan etis pada profesi yang di tekuni sangat penting, dan dapat mempengaruhi keberlangsungan profesi serta kepercayaan masyarakat terhadap profesi akuntan itu sendiri.

Seiring dengan berjalan nya waktu profesi akuntan semakin banyak diminati dan menjadi salah satu profesi yang sangat banyak serta dibutuhkan oleh kalangan pelaku industri dan bisnis. Jika sebelumnya banyak orang mengenal profesi akuntan hanya akuntan publik, dengan kemajuan teknologi dan banyak nya bidang usaha yang ada maka profesi akuntan tidak hanya pada jasa saja tetapi juga beberapa profesi lainnya (Fadli, 2014).

Etika merupakan bagian utama dalam profesi akuntan publik dan akuntan profesional serta menjadi tolak ukur dalam keberhasilan sebuah profesi. Para professional akuntan bertanggung jawab sesuai dengan fakta di lapangan. Ikatan Akuntan Indonesia (IAI) yang merupakan wadah organisasi akuntan di Indonesia telah memiliki Kode Etik IAI yang merupakan amanah dari AD/ART IAI dan peraturan yang berlaku, yaitu Keputusan Menteri Keuangan No. 263/KMK.01/2014 mengenai Penetapan Ikatan Akuntan Indonesia menjadi Organisasi Profesi Akuntan (IAI, 2016).

Dimana Peterson et al. (2001) menyatakan bahwa ethical beliefs merupakan penilaian subjektif yang dimiliki individu mengenai perilaku etis dan perilaku tidak etis. Penilaian etis yang dimiliki sesorang bisa menjadi penilaian yang relatif. Seseorang mungkin bisa menganggap bahwa hal yang dilakukan adalah hal yang benar, namun menurut penilaian orang lain hal tersebut salah.

Hal ini didukung oleh Velasquez (2005:20) yang menyatakan bahwa etika relatif yang merupakan bahwa tidak semua nya tindakan yang dilakukan setiap orang benar dan cara padang setiap orang berbeda-beda dan menjadi sesuatu yang mungkin dilakukan atau tidak mungkin untuk dilakukan, maka masyarakat yang berbeda akan memiliki ethical beliefs yang berbeda. Apakah tindakan tersebut benar atau salah secara moral, tergantung kepada pandangan dan keyakinan (beliefs) yang dimiliki masyarakat tersebut.

Di Indonesia sendiri isu pelanggaran etika mulai banyak bermunculan seperti kasus yang terjadi pada KAP Deloitte, yang merupakan salah satu KAP big four di Indonesia, Kasus ini bermula pada saat Deloitte mengaudit laporan keuangan atas transaksi pembelian obligasi berjangka (MTN) PT. SNP, yang kemudian pihak Otoritas Jasa Keuagan (OJK) dan juga pihak dari Kementerian Keuangan menemukan bahwa ada prosedur audit yang tidak dilakukan pihak auditor Deloitte terhadap laporan keuangan PT. SNP.

Dimana sikap kehati-hatian dan keyakinan etis yang perlu dimiliki auditor, serta pemahaman dan juga ketelitian mengenai sistem pencatatan yang digunakan perusahaan. Selain itu pihak Otoritas Jasa Keuangan (OJK) menemukan bahwa pelaksanaan audit dan standar prosedur yang dilakukan kantor akuntan publik yang diduga tidak sampai ke dokumen dasar (nasional.kontan.co.id).Dari kasus diatas dapat menunjukkan bahwa peranan besar keyakinan etis untuk sebuah pekerjaan akuntan ataupun auditor sebelum auditor atau akuntan publik mengambil sebuah keputusan, maka akuntan publik tersebut harus yakin bahwa keputusan yang diambil tidak mengabaikan resiko terhadap pekerjaan nya sendiri maupun terhadap kantor tempat dari auditor tersebut bekerja.

Dari berbagai pandangan yang ada profesi seorang akuntan sangat dibutuhkan dalam masyarakat, sebab seorang akuntan akan bekerja berdasarkan apa yang terjadi terhadap proses di dalam perusahaan itu sendiri dan juga harus berdasarkan keyakinan serta kepercayaan dari masyarakat sebagai pengguna dari jasa akuntan itu sendiri. Dalam melakukan tugas nya akuntan harus menjunjung tinggi kode etik dari profesi itu sendiri (Lubis, 2010:334). Selain kode etik 
profesi yang harus dijunjung tinggi oleh seorang akuntan, keyakinan etis seorang akuntan juga harus tetap dijaga, agar tidak terpengaruh oleh pihak-pihak yang dapat mempengaruhi keputusan yang akan dibuat Machfoedz (1997).

Kode etik juga menggambarkan karakter dari seorang akuntan dalam melaksanakan tugas nya, dengan adanya kode etik, akuntan dapat bekerja secara profesional dan bertanggung jawab penuh terhadap yang telah dilakukan, serta dapat terlindung dari perkara hukum jika terjadi kesalahan jika pekerjaan yang dilakukan dijalankan berdasarkan prosedur dan kode etik yang ada (Winarna dan Retnowati, 2004).

Penelitian dari Fine et al. (1988) menemukan bahwa akuntan profesional mempunyai kesempatan untuk dapat melakukan tindakan tidak etik dari pekerjaan yang dilakukan serta berbuat diluar kewenangan profesional nya (Husein, 2004). Disisi lain penelitian Chan dan Leung (2006) menemukan bahwa akuntan yang sudah berpengalaman dan profesional sangat rentan terlibat dalam kasus pelanggan etika.

Selain kode etik ada beberapa hal lain yang mempengaruhi profesionalisme akuntan dan keyakinan etis akuntan yakni usia, hal ini terbukti dalam penelitian Peterson, Rhoads dan Vaught (2001) yang mengatakan bahwa keyakinan etis (Ethical Beliefs) pada kategori perempuan usia muda lebih tinggi, dibandingkan para pria. Sementara pada kategori usia yang lebih tua, laki-laki yang memiliki kadar keyakinan etis yang tinggi dibandingkan perempuan. Pada kelompok lanjut usia perbedaan keyakinan etis antara laki-laki dan perempuan akan menghilang. Sebab pada fase ini sikap dan perilaku hampir sama kembali kepada sikap seperti anak-anak.

Variabel usia diambil dalam penelitian ini dikarenakan usia sangat rentan terhadap perubahan keyakinan seseorang, sebagai contoh jika seseorang masih dikategori usia anak-anak, maka keyakinan etis nya masih sangat baik, dikarenakan masih taat terhadap berbagai aturan yang ada, jika sudah beranjak remaja dan dewasa, adanya faktor-faktor lain seperti religiusitas, dapat membuat keyakinan etis nya bertambah maupun berkurang atau bahkan hilang, sebab keyakinan etis harus juga didasari oleh religiusitas ataupun etika moral yang baik, pernyataan ini sesuai dengan penelitian yang dilakukanoleh Catherine, Perryer (2002).

Alasan lainnya adalah mahasiswa yang berada pada semester atau tingkat awal takut akan membuat kesalahan yang berdampak terhadap perkuliahan yang dilakukan serta dapat diberikan sanksi ataupun hukuman, sedangkan mahasiswa pada tingkatan akhir lebih cenderung untuk bersikap tidak etis dikarenakan sudah merasa lebih senior dari pada mahasiswa tingkat awal dan sering mengabaikan moral serta perilaku yang seharusnya. Selain itu, mahasiswa dari jurusan akuntansi yang nantinya ingin berprofesi sebagai akuntan publik sedikit banyaknya akan dipengaruhi oleh judgment atau keputusan yang akan diambil, keputusan yang diambil tersebut juga akan dipengaruhi oleh keyakinan etis yang dimiliki akuntan profesioanal. Pernyataan ini sesuai dengan hasil penelitian dari Peterson, Rhoads (2001), dimana keyakinan etis mempengaruhi judgment (keputusan) seseorang.

Penelitian lainnya yang dilakukan oleh Oklesehan dan Hoyt (1996) mengemukan bahwa religiusitas memiliki pengaruh terhadap arah tindakan yang akan dilakukan seseorang, jika seseorang memiliki religiusitas yang baik maka individu tersebut akan menjauhi perilaku negatif yang dapat merusak moral nya. Maka dapat dikatakan agama sangat berperan besar dalam menentukan tindakan seseorang akan etis atau tidak. Penelitian lainnya yang dilakukan oleh Woodbine et al., (2009) mengatakan bahwa setiap agama dari kepercayaan yang dianut oleh seseorang memiliki perintah agar penganutnya berperilaku etis dan sesuai dengan norma yang ada. 
Tujuan dari penelitian ini adalah untuk membuktikan dan memperoleh bukti empiris sejauhmana pengaruh usia mempengaruhi keyakinan etis akuntan, sejauhmana pengaruh religiusitas terhadap keyakinan etis akuntan dan perbedaaan pandangan mahasiswa tingkat awal dengan mahasiswa tingkat akhir terhadap keyakinan etis akuntan. Maka dari itu peneliti tertarik untuk mengambil judul penelitian yakni: "Pengaruh Usia, Religiusitas Terhadap Keyakinan Etis Pada Akuntan"

\section{REVIEW LITERATUR DAN PENGEMBANGAN HIPOTESIS Teori Tindakan Berpikir (Theory Reasoned Action)}

Theory of Reasoned Action (TRA) merupakan teori yang pertama kali ditemukan oleh Fishbein dan Ajzen (1980). Dalam teori ini membahas bagaimana seseorang bertindak atas keyakinan yang dimilikinya serta sikap dan perilaku yang mendasari tindakan tersebut. Dalam teori ini juga membahas bagaimana keinginan seseorang berpengaruh terhadap perilaku orang tersebut. Dalam teori ini juga dibahas tindakan apa yang akan dilakukan seseorang dari keinginannya. Sebab tidak semua orang memiliki pertimbangan yang sama dari keputusan yang dibuat.

\section{Teori Behaviour (Etika)}

Etika merupakan aturan mengenai sikap maupun perilaku seseorang yang mencakup mengenai benar atau salah, baik atau buruk maupun penilaian moral terhadap tindakan yang dilakukan seseorang. Etika juga merupakan batasan-batasan dari tindakan yang tidak boleh dilakukan dari sebuah profesi atau pekerjaan. Dengan adanya etika perilaku dan tindakan seseorang akan dapat terkontrol dan tidak mengarah ke perbuatan maupun tindakan yang negatif (Duska, 2003). Etika juga membatasi seseorang untuk melakukan tindakan yang tidak etis, tindakan tidak etis yang terjadi dapat dipengaruhi oleh beberapa faktor yakni motivasi dan peraturan hukum (O'Leary dan Cotter, 2000).

\section{Keyakinan Etis (Ethical Beliefs)}

Menurut Dove Izraeli (1988:1) Keyakinan etis adalah perilaku atau keyakinan untuk dapat melihat apakah suatu keputusan yang sudah diambil tepat atau tidak serta dapat merubah sesuatu dari tindakan atau keputusan yang diambil tersebut. Selain itu keyakinan etis identik dengan pengamatan sikap dan perilaku seseorang dari apa yang ia lakukan. Keyakinan etis sangat diperlukan dalam pengambilan keputusan, agar keputusan yang diambil nantinya tidak merugikan kepentingan individu maupun kelompok.

Dalam penelitian Dove Izraeli (1988), ia melakukan penelitian terhadap manager untuk menguji apakah manager di perusahaan-perusahaan yang ada di daerah nya mempunyai keyakinan etis dari perspektif lintas budaya dan juga perilaku. Dari penelitan tersebut, hasil yang di dapat menunjukkan bahwa sebagian dari manager belum memiliki keyakinan etis di dalam dirinya.

\section{Usia (Age)}

Usia merupakan rentang waktu yang diberikan kepada seseorang dalam menjalankan kegiatan maupun aktivitas nya sehari-hari. Perhitungan usia pada manusia dibedakan menjadi tiga jenis diantaranya adalah: Usia kronologis, usia mental dan usia biologis. Usia kronologis merupakan usia bawaan dari diri manusia itu sendiri dihitung berdasarkan pada saat proses kelahairan hingga sampai pada kondisi menua. 
Usia mental disebut sebagai usia yang perhitungannya disesuaikan dengan kemampuan mental dari seseorang. Sebagai contoh jika seorang anak usia 5 tahun namun tidak dapat membaca dan menulis maka dapat dikategorikan usia mental anak tersebut sama dengan usia anak umur 2 tahun. Usia biologis, usia biologis dapat dilihat dari proses kehamilan seorang wanita, jika bayi yang dikandung memiliki anggota tubuh yang lengkap dan sempurna serta tidak mengalami masalah. Maka usia kandungan tersebut dapat dikatakan sebagai usia biologis. Usia biologis juga dipengaruhi oleh beberapa faktor lain diantaranya kondisi lingkungan sekitar rumah serta faktor makanan maupun nutrisi yang dikonsumsi, sehingga usia biologis dapat dipengaruhi (Lestiani, 2010).

\section{Pengelompokan Usia}

Penelitian yang dilakukan oleh Sumiati dan Ahmad (2010) mengelompokkan usia dalam beberapa bagian diantaranya adalah sebagai berikut:

1) Usia Kelahiran 0-1 Tahun

2) Usia Emas perkembangan anak-anak 2-10 Tahun

3) Usia Produktif = 11-20 Tahun

4) Usia Dewasa $=21-40$ Tahun

5) Usia Non produktif $=41-60$ Tahun

6) Usia Menua $=60$ Tahun keatas

Dalam penelitian ini untuk kategori usia dibedakan menjadi dua yakni remaja dan dewasa. Usia remaja merupakan usia peralihan dari masa kanak-kanak ke masa dewasa, yang meliputi perubahan biologis, perubahan psikologis dan perubahan sosial. Menurut penelitian yang dilakukan Ali \& Asrori (2004: 9). Usia remaja berlangsung antara umur 13 tahun - 21 tahun bagi wanita, sedangkan bagi pria berlangsung antara umur 13 tahun -22 tahun. Perkembangan usia remaja antara pria dan wanita memiliki perbedaan yang signifikan sebab, perkembangan biologis maupun psikologis dari segi pemikiran maupun emosi wanita cenderung lebih cepat dibandingkan pria.

Penelitian lainnya yang dilakukan oleh Hurlock (1993: 206-207) menyatakan bahwa usia remaja merupakan suatu periode transisi dari masa anak-anak menuju ke arah kematangan. Penelitian dari Hurlock tidak menyebutkan usia remaja sebagai masa transisi dari anak-anak menuju kedewasaan, tetapi lebih tepatnya dengan kematangan. Dikarenakan menurut Hurlock (1993) dewasa secara umum bersifat relatif dalam artian perkembangan psikologis dan cara berpikir seseorang belum tentu mengikuti perkembangan umur nya.

Sedangkan menurut penelitian yang dilalukan oleh Sarlito Wirawan (1991: 98) yang menyatakan bahwa usia remaja berkisar antara 11 sampai 24 tahun dengan alasan, bahwa usia 24 tahun merupakan batas usia maksimal untuk memberikan peluang seseorang untuk dapat masih bergantung kepada orang tua. Penelitian yang dilakukan oleh Andi Mappiare (1996: 27) menemukan bahwa usia remaja dibagi menjadi dua yakni usia remaja awal yang berkisar antara umur 13-18 tahun, dan usia remaja akhir yang berkisar antara 18-22 tahun.

\section{Religiusitas}

Religiusitas dapat diartikan sebagai wujud dari ketaatan seseorang terhadap ajaran (keyakinan) agama yang telah dianutnya, serta mengamalkan apa yang telah didapat dari ajaran agama tersebut kedalam kehidupan sehari-hari maupun aktivitas kehidupan yang dilakukan Fetzer (1999). Penelitian lainnya yang dilakukan Fetzer (1999) mengungkapkan bahwa religiusitas sangat berkaitan terhadap tugas keagamaan secara individual maupun kegiatan 
spiritual lainnya yang dapat meningkatkan rasa akan takut jika melakukan kesalahan besar yang merugikan banyak orang.

Selain itu religiusitas juga berkaitan antara bagaimana komitmen seseorang terhadap ajaran agama yang dianutnya serta komitmen, loyalitas maupun kontribusi yang telah diberikan dari agama yang dianut tersebut. Penelitian lainnya yang dilakukan oleh Kendler, et.al (2003) mengungkapkan bahwa religiusitas tidak hanya mengenai kepercayaan dan keyakinan seseorang melainkan bagaimana keyakinan serta kepercayaan akan prinsip-prinsip agama secara menyeluruh.

Skala lainnya yakni skala religiusitas yang ditemukan oleh Kendler, et.al., (2003) dimana pada skala ini terdiri dari 78 item yang mengukur religiusitas secara umum, pengaplikasian religiusitas dalam kehidupan sehari-hari, religiusitas secara sosial, religiusitas untuk saling memaafkan, religiusitas yang meyakini ketentuan dan hukuman yang diberikan dari sang pencipta terhadap tindakan yang dilakukan, religiusitas dari sikap selalu bersyukur dan berterima kasih, religiusitas yang tidak memiliki rasa dendam kepada orang lain, serta religiusitas yang meyakini keberadaan sang pencipta dalam setiap kegiatan yang dilakukan.

\section{Penelitian Terdahulu}

Izaeli (1988) Keyakinan etis dan perilaku dari para mananger pendekatan dari berbagai perspektif budaya. Hasil penelitian membuktikan bahwa para manager menilai diri mereka lebih baik pada dimensi keyakinan dan dari hasil regresi menunjukkan bahwa kebijakan organisasi yang jelas tidak berpengaruh signifikan terhadap perilaku etis. Chris Perryer, Catherine Jordan (2002) Pengaruh Gender, Usia, budaya dan faktor lainnya yang mempengaruhi keyakinan etis: studi komparatif pada Negara Australia dan Singapura.

Hasil penelitian membuktikan bahwa usia, gender berpengaruh signifikan terhadap keyakinan etis, sedangkan faktor lain dari lingkungan kerja juga mempengaruhi dari keyakinan etis yang ada. Dane Peterson, Angela Roads, Bobby C. Vaught (2001) Studi Keyakinan Etis Dari Bisnis Profesional. Hasil penelitian membuktikan bahwa Gender mempengaruhi keyakinan etis dan Usia mempengaruhi keyakinan etis dimana pada usia perempuan yang lebih muda keyakinan etis memiliki peningkatan.

\section{Pengaruh Usia Terhadap Keyakinan Etis (Ethical Beliefs) pada Mahasiswa Akuntansi Di Kota Padang}

Usia merupakan salah satu faktor yang mempengaruhi cara pandang seseorang serta dapat mempengaruhi tingkat pemikiran etis mahasiswa akuntansi. Menurut penelitian yang dilakukan Comunale et al. (2006) menemukan bahwa pada kategori usia muda, seseorang dapat kehilangan fokus perhatian terhadap tindakan yang etis dibandingkan pada kategori usia yang lebih tua. Hal ini dapat terjadi disebabkan pada kategori usia yang lebih tua mereka lebih dapat mengendalikan emosi mereka, serta banyak mempertimbangkan faktor moral dibandingkan faktor lainnya (Dawson, 1997). Pada tingkatan usia tertentu, seseorang akan menemukan apa arti pentingnya pengendalian diri dan sikap moral yang dapat digunkaan dalam kegiatan sehari-hari (Lawrence dan Shaub, 1997).

Dalam hal usia mempengaruhi keyakinan etis seseorang, dapat juga dilihat dari moral dan norma hidup yang digunakan seseorang, sebab jika seseorang menggunakan moral dan menaati norma yang berlaku dalam kehidupan sehari-hari maka dapat menumbuhkan keyakinan etis yang lebih baik, serta mau mendengarkan masukan dari orang lain atas perilaku maupun tindakan menyimpang yang dilakukan (Trevino L., 1992). 
Penelitian Thoma (1984) dalam Chan dan Leung (2006), menemukan bahwa sikap dan etika yang timbul dari dalam diri seseorang dapat dipengaruhi oleh usia seseorang. Hal ini didukung oleh penelitian yang dilakukan Perryer, Jordan (2002) yang menemukan bahwa usia menjadi prediksi keyakinan etis (ethical beliefs) mahasiswa MBA. Akuntan yang telah memiliki banyak pengalaman lebih cenderung memiliki keyakinan etis (ethical beliefs) dalam melaksanakan dan mengambil keputusan yang dibuat, hal ini dapat terjadi dikarenakan akuntan professional atau akuntan senior dapat mengontrol emosinya, yang dapat juga dipengaruhi oleh pertimbangan moral dan resiko yang akan dihadapi dari keputusan yang akan diambil.

Maka berdasarkan dari penjelasan diatas dapat diambil kesimpulan bahwa hipotesis dalam penelitian ini adalah sebagai berikut:

$\mathrm{H}_{1}$ : Usia berpengaruh signifikan positif terhadap keyakinan etis.

\section{Pengaruh Religiusitas Terhadap Keyakinan Etis (Ethical Beliefs) Pada Mahasiswa Akuntansi di Kota Padang}

Religiusitas menurut Sulistiani (2011:20) merupakan pemahaman individu secara menyeluruh terhadap ajara agama yang dianutnya, serta mengaplikasikan ajaran agama yang didapat kedalam kehidupan sehari-hari, baik melalui interaksi sosial maupun hubungan antar sesama. Dengan adanya religiusitas diharapkan seseorang dapat menjadi pribadi yang lebih baik dalam segala perilaku, serta dapat dijadikan landasan untuk keyakinan etis terhadap keputusan yang akan diambil di dalam bekerja maupun beraktivitas.

Religiusitas juga dapat dijadikan sebagai dasar untuk menentukan tindakan yang dilakukan apakah dapat diterima oleh akal sehat atau tidak atau dapat diartikan untuk "pembeda antara baik dan yang buruk", dalam arti kata lain dapat dijadikan dasar seseorang untuk mengambil sebuah keputusan dengan berlandaskan keyakinan etis yang dimilikinya. Penelitian yang dilakukan Alport dan Ross (1967:5) mengatakan religiusitas menjadi salah satu faktor yang penting dalam hubungan sosial antar individu.

Tingkat religiusitas seseorang juga berbeda-beda bergantung dari seberapa banyak ilmu agama yang dijadikan sebagai landasan hidup. Selain itu menurut ilmu psikologi dalam bidang sosial religiusitas juga dipengaruhi oleh kebutuhan masing-masing individu, dikarenakan masing-masing individu mempunyai tujuan yang berbeda dalam menjalani kehidupan nya. Penelitian yang dilakukan oleh Alport dan Ross (1967) juga menemukan bahwa religiusitas memiliki dua konsep arah yakni berdasarkan aspek motivasi yang mendasari seseorang ingin menjadi religius dan tujuan yang ingin dicapai dari sikap religius itu sendiri. Penelitian yang dilakukan Allport dan Ross (1967) juga membagi religiusitas menjadi dua kelompok yakni religiusitas dari dalam diri manusia itu sendiri, dan religiusitas yang dipengaruh dari faktor luar seperti lingkungan, moral serta aturan yang ada dalam kehidupan bermasyarakat.

Selain itu penelitian yang dilakukan Glover (1997) menemukan bahwa selain moral ada beberapa faktor lain yang mempengaruhi karakteristik seseorang individu dari agama dan kepercayaan yang dianutnya. Penelitian lainnya yang dilakukan oleh Allport (1950) menemukan bahwa faktor lingkungan juga menjadi salah satu penentu dalam menentukan keberhasilan religiusitas seseorang, sebagai contoh jika seorang individu tumbuh dan besar dari lingkungan yang telah menerapkan nilai-nilai religiusitas dari sejak dini atau pada usia anak-anak, maka akan berpengaruh besar terhadap perkembangan pribadi orang tersebut.

Penelitian yang dilakukan Donahue (1985) juga menemukan bahwa religiusitas dari dalam diri manusia sangat berguna sebagai landasan dalam menjalankan setiap kegiatan serta menjauhkan manusia dari perbuatan menyimpang dan mau mengakui kesalahan yang telah 
diperbuat. Penelitian lainnya yang dilakukan (Grasmick, Bursik, \& Cochran, 1991), Menemukan bahwa mereka yang tidak berafiliasi antara moral individu yang dimiliki dengan orientasi religiusitas yang ada lebih cenderung untuk menipu. Sehingga dengan kata lain, jika seseorang yang memiliki religiusitas yang taat maka ia juga akan memiliki keyakinan etis yang lebih terhadap tindakan yang akan ia ambil (Lau, 2011). Dari penjelasan diatas maka dapat diambil kesimpulan bahwa hipotesis dari penelitian ini adalah sebagai berikut:

$\mathrm{H}_{2}$ : Religiusitas berpengaruh signifikan positif terhadap keyakinan etis (ethical beliefs)

\section{Terdapat Perbedaan Pandangan Mengenai Keyakinan Etis Antara Mahasiswa Program Studi Akuntansi S1 Tingkat Awal Dengan Mahasiswa Program Studi Akuntansi S1 Tingkat Akhir.}

Pendidikan pada perguruan tinggi melibatkan banyak aspek yang harus diperhatikan salah satunya adalah Mahasiswa dan Mahasiswi yang menjadi objek dalam menuntut ilmu pengetahuan (KBBI, 2018). Setiap mahasiswa memiliki cara dan pandangan nya masing-masing dalam memecahkan sebuah persoalan maupun menghadapi kegiatan yang ada didalam lingkungan kampus. Didalam kehidupan kampus tidak jarang antara mahasiswa senior dengan mahasiswa junior memiliki perbedaan dan berselisih paham. Mahasiswa senior atau mahasiswa pada tingkat akhir merasa diri mereka harus dihormati lebih dibandingkan mahasiswa junior atau tingkat awal.

Pendapat lainnya juga ditemukan pada penelitian yang dilakukan oleh Rawwas et al (2007) yang melakukan penelitian mahasiswa tingkat Magister Business Administration (MBA) yang idealis dan juga tidak toleran yang berasal dari Negara bagian Amerika Serikat yang cenderung berperilaku etis, dibandingkan dengan mahasiswa Magister Business Administration $(M B A)$ yang idealis dan juga tidak toleran yang berasal dari Negara Hongkong yang cenderung bertindak secara moral.

Mahasiswa pada semester akhir atau senior diduga mempunyai keyakinan etis dan sikap yang lebih etis dibandingkan mahasiswa pada semester pertama atau junior dalam perihal pembuatan dan penyusunan laporan keuangan perusahaan, sebab mahasiswa pada tingkat akhir telah mendapatkan mata kuliah mengenai penyusunan laporan keuangan yang belum didapatkan oleh mahasiswa tingkat awal atau junior. Dari penjelasan yang ada maka dapat disimpulkan hipotesis dalam penelitian ini adalah sebagai berikut:

$\mathrm{H}_{3}$ : Mahasiswa akuntansi pada semester akhir (Tingkat Akhir) mempunyai keyakinan etis yang lebih baik dibandingkan Mahasiswa akuntansi semester awal (Tingkat Awal)

\section{Kerangka Konseptual I Model Penelitian I}

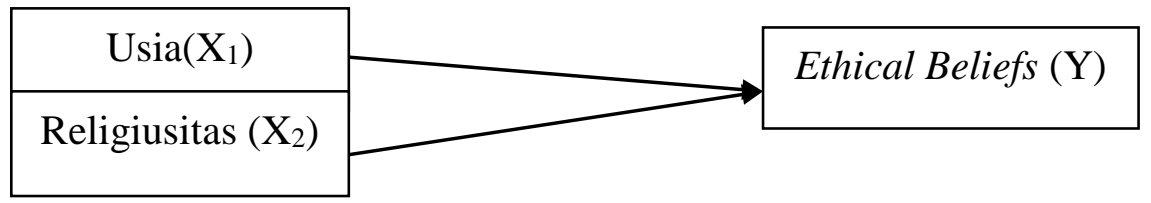

Gambar 1 Kerangka Konseptual I 


\section{Kerangka konseptual II Model Penelitian II}

\begin{tabular}{|c|c|c|}
\hline $\begin{array}{c}\text { Ethical beliefs mahasiswa } \\
\text { S1akuntansi tingkat awal }\end{array} \stackrel{\mathbf{Y}}{\longleftrightarrow} \begin{array}{l}\text { Ethical Beliefs mahasiswa } \\
\text { S1 akuntansi tingkat akhir }\end{array}$ \\
\hline
\end{tabular}

\section{Gambar 2 Kerangka Konseptual II}

\section{METODE PENELITIAN}

Dari penjelasan yang telah dikemukan pada latar belakang dan juga kajian teori maka dapat diambil kesimpulan bahwa penelitian yang dilakukan ini dapat dikategorikan sebagai penelitian kuantitatif. Dimana data yang digunakan merupakan data yang telah diolah menggunakan beberapa software statistik serta bertujuan untuk mencari bukti empiris baru dari penelitian yang telah pernah dilakukan sebelumnya. Dengan menggunakan beberapa pendekatan yang mendukung dalam penelitian ini (Sugiyono, 2013:2).

\section{Populasi dan Sampel}

Dunia pendidikan memiliki perkembangan yang cukup cepat dan membutuhkan sangat banyak calon professional dalam berbagai bidang, salah satu profesi yang banyak diminati adalah profesi akuntan. Populasi yang digunakan pada penelitian ini adalah mahasiswa program studi S1 akuntansi yang ada di kota Padang.

\section{Sampel}

Sampel penelitian menggunakan pendekatan Purposive Sampling, yang mana sampel yang akan dimasukkan kedalam penelitian ini harus memenuhi beberapa kriteria yang telah ditetapkan serta harus memenuhi dari kriteria tersebut. Beberapa kriteria yang harus dipenuhi antara lain adalah: Mahasiswa yang masih aktif menjalankan kegiatan perkuliah dan terdaftar pada program studi akuntansi jenjang S1 di Kota Padang. Dikarenakan sangat banyak nya penyelanggara pendidikan tinggi yang terdapat di Kota Padang, maka peneliti hanya mengambil sampel pada perguruan tinggi terkemuka yang ada di Kota Padang sebagai sampel penelitian. Diantaranya adalah Universitas Negeri yakni: Universitas Andalas, Universitas Negeri Padang, sedangkan Universitas Swasta yakni: Universitas Bung Hatta dan Universitas Putra Indonesia YPTKI.

Mahasiswa S1 akuntansi tingkat awal (tahun masuk 2018, 2017 dan 2016), dimana mahasiswa dianggap belum memahami perilaku etis dan tidak etis dikarenakan belum lulus mata kuliah audit dan etika bisni dan mahasiswa S1 akuntansi tingkat akhir (tahun masuk 2015) dimana mahasiswa dianggap memahami perilaku etis dan perilaku tidak etis karena telah lulus mata kuliah audit dan etika bisnis.

\section{Jenis, Sumber dan Teknik Pengumpulan Data}

Jika dilihat dari data yang telah diperoleh pada penelitian ini, maka data yang digunakan dikategorikan sebagai data Subjek. Data subjek merupakan data yang peroleh secara langsung dilapangan dengan membagikan kuisioner berdasarkan pengalaman, pengamatan karakteristik masing-masing individu serta sikap dari masing-masing individu yang menjawab yang dijadikan sebagai dasar pembuatan penelitian. 
Sumber data dalam penelitian ini menggunakan data primer, yakni data yang diperoleh secara langsung dilapangan dengan melihat dan mengamati masing-masing responden yang akan mengisi kuisioner tanpa adanya perantara. Hasil nya merupakan jawaban dari item pertanyaan yang diajukan di dalam kuisioner penelitian.

\section{Teknik Pengumpulan Data}

Studi kepustakaan digunakan untuk mengumpulkan data pendukung, maupun data acuan serta mencari literatur-literatur dan juga buku serta bahan bacaan lainnya yang berguna sebagai landasan penelitian serta penguat dari teori-teori yang akan digunakan dalam penelitian, dan membantu dalam menambah referensi penelitian

Sumber data yang digunakan berasal dari kuisoner yang dibagikan secara personal ke masing-masing responden yang menjadi sampel penelitian. Setelah kuisioner dibagikan peneliti memberikan arahan kepada para responden dalam mengisi kuisioner yang telah diberikan. Selanjutnya responden mengisi kuisioner yang telah diberikan sesuai petunjuk yang telah dijelaskan sebelumnya.

\section{Instrumen Penelitian}

Penelitian ini menggunakan kuisioner sebagai instrumen penelitian. Kuisioner yang telah disusun menggunakan skala likert dimana jawaban setiap responden memiliki beberapa alternatif jawaban, kemudian masing-masing jawaban akan diberikan skor seperti : Sangat Setuju (SS), Setuju (S), Kurang Setuju (KS), Tidak Setuju (TS), dan Sangat Tidak Setuju (STS).

Dalam penelitian yang ia lakukan usia di bedakan berdasarkan rentang umur masingmasing responden. Usia mahasiswa tingkat awal dikategorikan remaja 18-21 tahun, usia mahasiswa tingkat akhir dikategorikan dewasa dari rentang 21-25 tahun, dan juga dikategorikan berdasarkan semester yang ditempuh pada saat tahun ajaran atau kurikulum yang berjalan (Hurlock, 1980).

Variabel Religiusitas mengadopsi dari penelitian Kendler, et.al. (2013). Indikator yang akan dipakai dalam penelitian dan item pertanyaan yang akan dipakai dalam kuisioner telah diterjemahkan sesuai kebutuhan bahasa penelitian. Skala yang digunakan Kendler, et al. (2013) telah banyak digunakan dalam penelitian dibidang perilaku dan perilaku serta psikologi yang berfokus kepada agama. Variabel keyakinan etis (ethical beliefs) dinilai dengan menggunakan item pernyataan didalam kuisioner mengenai kecurangan akademik dengan jumlah item pernyataan sebanyak 22 item pernyataan, item pernyataan dibuat berdasarkan skala likert dengan penilai skor satu (1) sampai dengan skor lima (5). Untuk Variabel Keyakinan etis Instrumen penelitian menggunakan pengukuran yang telah dilakukan sebelumnya oleh Rawwas et al. (2007) dengan dibagi menjadi menjadi empat dimensi.

\section{Metode Analisis Data \\ Uji Validitas dan Realibilitas}

Uji validitas merupakan salah satu uji yang digunakan untuk menentukan apakah item pertanyaan maupun pernyataan yang terdapat di dalam kuisioner telah validitas digunakan untuk untuk mengukur sah atau valid tidaknya suatu kuesioner.Uji validitas pada penelitian ini menggunakan program software SPSS dengan menggunakan perhitungan Corrected Product Moment hasil yang diperoleh dapat dikatakan valid jika nilai $r_{\text {hitung }}>r_{\text {tabel }}$ atau dapat dikatakan bernilai positif. 
Uji Reliabilitas digunakan untuk mengukur apakah hasil dari jawaban responden dalam menjawab kuisioner sama atau stabil dari item pernyataan satu ke item pernyataan yang lainnya. Kuisioner yang digunakan dapat dikatakan reliabel jika nilai Cronbach's Alpha $(\alpha)$ memiliki tingkat persentase harus lebih dari 0,8.

Uji Normalitas Uji normalitas digunakan untuk melihat model regresi yang digunakan dalam penelitian. Uji normalitas melihat apakah data yang akan diolah telah berdistribusi secara normal atau tidak, serta tidak adanya variabel pengganggu yang dapat mempengaruhi distibusi atau sebaran data (Ghozali, 2011). Uji HomogenitasUji homogenitas dilakukan jika sampel yang digunakan dalam penelitian berasal dari populasi yang memiliki variansi yang sama. Uji homogenitas dalam penelitian ini dilakukan berdasarkan nilai rata-rata yang didapat dari hasil jawaban responden, kemudian diberikan penjelasan mengenai populasi yang memiliki variansi yang sama tersebut. Uji Regresi Berganda dalam penelitian ini untuk melakukan pengolahan data statistik digunakan Uji regresi berganda (Multiple Regression Analysis). Uji regresi berganda dilakukan apabila menggunakan lebih dari dua variabel penelitian. Uji regresi berganda juga dilakukan untuk menguji apakah hipotesis yang telah dibuat terbukti didalam penelitian yang telah dilakukan.

\section{HASIL DAN PEMBAHASAN Gambaran Umum Objek Penelitian}

Data dalam penelitian ini merupakan data primer yakni berupa kuesioner atau angket. Kuesioner yang telah dibuat selanjutnya dilakukan penyebaran kuisioner secara lansung kepada mahasiswa strata satu (S1) program studi akuntansi yang berada di kota padang dari berbagai universitas diantaranya adalah dari mahasiswa dan mahasiwi Universitas Negeri Padang, Universitas Andalas, Universitas Bung Hatta, serta Universitas Putera Indonesia YPTKI.

Penyebaran kuesioner dilakukan selama lebih dari satu bulan. Sebelum melakukan penelitian peneliti meminta izin kepada jurusan dari masing-masing universitas yang dijadikan sebagai objek penelitian, dengan membawa surat rekomendasi dari kampus peneliti. Setelah izin didapatkan maka peneliti melakukan koordinasi dengan petugas administrasi pada bagian kampus yang menjadi objek penelitian untuk selanjutnya dapat mengetahui jadwal kuliah dari responden yakni mahasiwa tingkat awal dan tingkat akhir di masing-masing objek penelitian.

Setelah mengetahui jadwal kelas mahasiswa tingkat awal dan tingkat akhir yang menjadi responden. Peneliti melakukan koordinasi dengan ketua kelas pada masing-masing angkatan untuk dapat membagikan kuesioner setelah jam mata kuliah berakhir. Selanjutnya kuesioner yang telah dibagikan dan di isi secara lengkap saat itu juga kuesioner langsung dikumpulkan. Jumlah kuesioner yang telah disebar sebanyak 356 kuesioner. Dari keseluruhan kuesioner yang ada secara keseluruhan dapat diolah dan dianalisis dikarenakan telah di isi secara lengkap. Rincian dari peyebaran dan pengembalian kuesioner dapat dilihat pada Tabel 4.1 dari tabel tersebut dapat diketahui tingkat pengembalian (respon rate) sebesar 100\%. Hasil dari penyebaran dan pengembalian kuesioner dapat dilihat pada tabel 1 berikut: 
Tabel 1

Penyebaran dan Pengembalian Kuesioner

\begin{tabular}{lc}
\hline \multicolumn{1}{c}{ Keterangan } & Jumlah Kuesioner \\
\hline Jumlah Kuesioner yang disebar & 356 \\
\hline Jumlah Kuesioner yang kembali & 356 \\
\hline $\begin{array}{l}\text { Jumlah Kuesioner yang lengkap dan dapat } \\
\text { diolah }\end{array}$ & 356 \\
\hline \multicolumn{2}{c}{ Respon Rate } \\
\hline
\end{tabular}

Sumber : Data primer yang diolah, Tahun 2019

\section{Karakteristik Responden}

Ada beberapa karakteristik responden yang menjadi sampel dalam penelitian ini adalah mahasiswa dan mahasiswa strata satu (S1) akuntansi di kota Padang. Berikut gambaran karakteristik responden yang menjadi sampel penelitian:

\section{Responden Berdasarkan Tingkatannya}

Berdasarkan kuisioner yang dikumpulkan, diperoleh data mengenai tingkatan responden. Dalam penelitian ini tingkatan mahasiswa dikategorikan menjadi dua kategori, yaitu mahasiswa tingkat akhir (tahun masuk 2014-2015) dan mahasiswa tingkat awal (tahun masuk 2016-2018). Adapun data tentang jumlah responden berdasarkan tingkatannya tersusun pada tabel 2 sebagai berikut:

Tabel 2 Responden Berdasarkan Tingkatannya

\begin{tabular}{cccc}
\hline No & Tingkatannya & Jumlah & Persentase \\
\hline 1 & Mahasiswa Tingkat Awal & 260 & $73,03 \%$ \\
\hline 2 & Mahasiswa Tingkat Akhir & 96 & $26,97 \%$ \\
\hline & Jumlah & 356 & $100 \%$ \\
\hline
\end{tabular}

Sumber : Data primer yang diolah, Tahun 2019

\section{Responden Berdasarkan Usia}

Berdasarkan hasil kuisioner yang telah di isi dan dikumpulkan, maka dapat diperoleh data mengenai responden berdasarkan usia. Variabel usia dalam penelitian ini dibagi menjadi dua kategori yakni remaja dan dewasa. Dengan rincian sebagai berikut:

Tabel 3. Responden Berdasarkan Usia Responden

\begin{tabular}{llcc}
\hline No & Kategori Usia & Jumlah & Persentase \\
\hline 1 & Remaja & 278 & $78,09 \%$ \\
\hline 2 & Dewasa & 78 & $21,91 \%$ \\
\hline & Jumlah & $\mathbf{3 5 6}$ & $\mathbf{1 0 0} \%$ \\
\hline
\end{tabular}

Sumber : Data primer yang diolah, Tahun 2019

\section{Responden Berdasarkan Religiusitas}

Berdasarkan kuisioner yang telah di isi dan dikumpulkan, maka diperoleh data responden berdasarkan Religiusitas. Dalam hal ini responden dibagi berdasarkan kepercayaan atau 
keyakinan dari agama yang dimiliki oleh masing-masing responden. Adapun data mengenai responden berdasarkan tingkat religiusitas nya dapat dilihat pada Tabel 4 sebagai berikut:

Tabel 4. Responden Berdasarkan Religiusitas

\begin{tabular}{clcc}
\hline No & Agama / Religiusitas & Jumlah & Persentase \\
\hline 1 & Islam & 308 & $86,62 \%$ \\
\hline 2 & Kristen Katolik & 26 & $7,30 \%$ \\
\hline 3 & Kristen Protestan & 20 & $5,62 \%$ \\
\hline 4 & Buddha & 2 & $0,56 \%$ \\
\hline \multicolumn{2}{c}{ Jumlah } & $\mathbf{3 5 6}$ & $\mathbf{1 0 0 \%}$ \\
\hline
\end{tabular}

Sumber: Data primer yang diolah, 2019

\section{Statistik Deskriptif}

Statistik deskriptif dalam penelitian ini disajikan untuk memberikan gambaran mengenai karakteristik dari masing-masing variabel penelitian, antara lain yakni nilai minimum dari hasil kuesioner penelitian, nilai maximum dari jawaban kuesioner responden, nilai tengah atau mean dari data tabulasi kuesioner penelitian serta standar deviasi yang diperoleh. Gambaran dari masing-masing variabel tersebut dapat lihat pada tabel 5 sebagai berikut:

Tabel 5

Statistik Deskriptif Variabel Penelitian

\begin{tabular}{lccccc}
\hline & $\mathrm{N}$ & Minimum & Maximum & Mean & Std. Deviation \\
\hline Usia & 356 & 0 & 1 & .34 & .474 \\
\hline Religiusitas & 356 & 82 & 305 & 228.77 & 27.554 \\
\hline Keyakinan etis & 56 & 62 & 110 & 91.71 & 11.000 \\
\hline Valid N (listwise) & 356 & & & &
\end{tabular}

Sumber: Data primer diolah, Tahun 2019

Maka dari data tabel 4.6 analisis statistik deskriptif pada variabel usia diperoleh nilai maximum 1 (satu) dan nilai minimum yakni 0 (nol). Serta memiliki nilai mean atau nilai tengah yakni 0,34 dan memiliki standar deviasi sebesar 0,474. Sedangkan untuk variabel religiusitas pada penelitian ini, memiliki nilai maximum yakni 110 dan nilai minimum yakni sebesar 82, untuk nilai mean pada variabel religiusitas yakni sebesar 228,77 serta mempunyai nilai standar deviasi yakni sebesar 27,554.

\section{Usia}

Variabel usia merupakan variabel yang sangat penting dalam penelitian ini sebab variabel usia dapat dijadikan indikator untuk melihat keyakinan etis mana yang lebih baik antara mahasiswa pada tingkat awal dengan mahasiswa pada tingkat akhir. Dalam penelitian ini variabel usia dibagi menjadi dua kategori yakni remaja dan dewasa, serta dihitung dengan menggunakan teknik analisis dummy dimana setiap kategori diberi kode. Usia pada kategori remaja diberi kode nilai 0 (Nol), sedangkan pada kategori Dewasa diberi kode nilai satu (1) (Perterson, 2002). 


\section{Uji Normalitas}

Uji normalitas dilakukan untuk dapat melihat apakah distribusi frekuensi data yang digunakan dalam penelitian berdistribusi secara normal atau tidak. Uji normalitas dalam penelitian ini dengan menggunakan uji one sample kolmogrov - smirnov. Data penelitian dapat dikatakan normal apabila dari hasil pengolahan data dengan program SPSS menunjukkan anggka nilai signifikansi lebih besar $>$ dari 0,05 . Jika nilai sig yang diperoleh dari hasil pengolahan dengan program SPSS lebih kecil < daripada 0,05, maka dapat dikatakan data tidak berdistribusi secara normal. Data untuk uji normalitas dalam penelitian ini dapat dilihat pada Tabel 6 sebagai berikut ini

Tabel 6. Uji Normalitas One Sample Kolomgrov - Smirnov

\begin{tabular}{llc}
\hline & \multicolumn{1}{c}{$\begin{array}{c}\text { Unstandardized } \\
\text { Residual }\end{array}$} \\
\hline $\mathrm{N}$ & & \multicolumn{1}{c}{346} \\
\hline Normal Parameters $^{a, b}$ & Mean & .0000000 \\
\cline { 2 - 3 } & Std. Deviation & 1.039 .098 .018 \\
\hline Most Extreme & Absolute & .046 \\
\cline { 2 - 3 } Differences & Positive & .037 \\
\cline { 2 - 3 } & Negative & -.046 \\
\hline Test Statistic & & .046 \\
\hline Asymp. Sig. (2-tailed) & & $.073^{\mathrm{c}}$ \\
\hline
\end{tabular}

Sumber : Data primer yang diolah tahun 2019

Dari hasil pengolahan data dengan program SPSS Versi 23 diatas dapat diambil kesimpulan bahwa nilai Asymp Sig (2-tailed) sebesar 0,07 atau lebih besar > dari 0,05, sehingga dapat diambil kesimpulan bahwa data dalam penelitian ini berdistribusi secara normal.

\section{Uji Heterokedastisitas}

Uji Heterokedastisitas bertujuan untuk menguji apakah dalam suatu model regresi terjadi ketidaksamaan varians dan residual antara satu pengamatan ke pengamatan yang lain. Uji heterokedastisitas dapat dilakukan dengan menggunakan dua metode yakni dengan metode scatterplot atau juga dengan menggunakan uji glejser untuk mendeteksi apakah terjadinya gejala heterokedastisitas atau tidak didalam penelitian yang dilakukan.Jika varians dari residual suatu pengamatan ke pengamatan lain tetap, maka disebut homokedastisitas dan jika berbeda maka disebut heterokedastisitas.

Dalam penelitian ini menggunakan uji glejser dalam pengujian heterokedastisitas dimana apabila nilai sig lebih besar > dari 0,05 maka dapat diambil kesimpulan tidak terjadinya gejala heterokedastisitas, sebaliknya apabila nilai sig lebih kecil < dari 0,05 maka dapat diambil kesimpulan bahwa terdapat gejala heterokedastisitas dari data penelitian. 
Tabel 7. Uji Heterokedastisitas

\begin{tabular}{c|c|c|c|c|c|c}
\hline \multicolumn{7}{c}{ Coefficients $^{a}$} \\
\hline \multirow{2}{*}{ Model } & & $\begin{array}{c}\text { Unstandardized } \\
\text { Coefficients }\end{array}$ & & $\begin{array}{c}\text { Standardized } \\
\text { Coefficients }\end{array}$ & $\mathrm{t}$ & Sig. \\
\hline & & $\mathrm{B}$ & $\begin{array}{c}\text { Std. } \\
\text { Error }\end{array}$ & Beta & & \\
\hline \multirow{1}{*}{} & (Constant) & 6.295 & 2.770 & & 2.273 & .024 \\
\hline & Usia & -1.290 & .684 & -.102 & - & .060 \\
\hline & Religiusitas & .011 & .012 & .051 & .938 & .349 \\
\hline
\end{tabular}

Sumber: Data primer diolah, Tahun 2019

Dari data pada tabel 4.10 diatas dapat diambil kesimpulan bahwa tidak terjadi gejala heterokedastisitas antar variabel penelitian. Hal ini dapat dilihat dari nilai sig yang diperoleh untuk variabel usia yakni sebesar 0,06 atau lebih besar > dari 0,05 sehingga dapat diartikan bahwa pada variabel usia tidak terjadi gejala heterokedastisitas.

\section{Uji Multikoloniaritas}

Uji multikolinearitas merupakan pengujian yang dilakukan untuk melihat model penelitian apakah terjadi hubungan yang sempurna antara variabel bebas, sehingga sulit untuk memisahkan pengaruh antara variabel-variabel tersebut secara individu terhadap variabel terikat. Dasar pengambilan keputusan dalam uji multikolinearitas dapat dilihat melalui nilai VIF (Variance Inflation Factor) dan juga nilai tolerance dari hasil pengujian dengan program SPSS. Data hasil pengolahan data dengan program SPSS terkait dengan Uji multikolinearitas dalam penelitian ini dapat dilihat pada tabel 8 sebagai berikut:

Tabel 8. Hasil Olah Data Uji Multikolinearitas

\begin{tabular}{|c|c|c|c|c|c|c|c|c|}
\hline \multicolumn{9}{|c|}{ Coefficients $^{a}$} \\
\hline \multirow{2}{*}{\multicolumn{2}{|c|}{ Model }} & \multicolumn{2}{|c|}{$\begin{array}{c}\text { Unstandardized } \\
\text { Coefficients }\end{array}$} & \multirow{2}{*}{$\begin{array}{c}\begin{array}{c}\text { Standardized } \\
\text { Coefficients }\end{array} \\
\text { Beta }\end{array}$} & \multirow[b]{2}{*}{$t$} & \multirow[b]{2}{*}{ sig } & \multicolumn{2}{|c|}{$\begin{array}{c}\text { Collinearity } \\
\text { Statistics }\end{array}$} \\
\hline & & $B$ & $\begin{array}{c}\text { Std. } \\
\text { Error }\end{array}$ & & & & Tolerance & $V I F$ \\
\hline \multirow{3}{*}{1} & (Constant) & 113,04 & 4,791 & & 23,59 & 0 & & \\
\hline & Usia & 4,426 & 1,184 & 0,191 & 3,739 & 0 & 0,959 & 1,04 \\
\hline & Religiusitas & $-0,1$ & 0,02 & $-0,25$ & $-4,9$ & 0 & 0,959 & 1,04 \\
\hline
\end{tabular}

a. Dependent Variable: Keyakinan Etis

Sumber: Data primer diolah, Tahun 2019

\section{Uji Homogenitas}

Uji homogenitas dilakukan untuk mengetahui apakah varian data yang digunakan dalam penelitian ini Uji homogenitas data Keyakinan etis dan Religiusitas kepada mahasiswa akuntansi yang ada di kota padang dapat dilihat pada tabel 9 sebagai berikut: 
Tabel 9. Hasil Uji Homogenitas

\begin{tabular}{l|c|c|c|c}
\hline \multicolumn{5}{c|}{ Test of Homogeneity of Variances } \\
\hline & $\begin{array}{c}\text { Levene } \\
\text { Statistic }\end{array}$ & df1 & df2 & Sig. \\
\hline Keyakinan Etis & 0,015 & 1 & 354 & 0,9 \\
\hline Religiusitas & 0,239 & 1 & 354 & 0,63 \\
\hline
\end{tabular}

Sumber : Data Primer yang diolah tahun 2019

Berdasarkan hasil yang diperoleh pada tabel 9 diatas, dapat diketahui nilai signifikansi (sig) dari data keyakinan etis atau ethical beliefs sebesar 0,901 dan nilai signifikansi (sig) untuk Religiusitas sebesar 0,625. Sehingga dapat diambil kesimpulan bahwa data keyakinan etis dan religiusitas mempunyai varian yang sama atau homogen karena hasil pengolahan data nilai sig lebih besar $>$ dari alfa $(\alpha)$.

\section{Analisis Data}

\section{Hasil Analisis Regresi}

Teknik analisis regresi berganda digunakan untuk mengetahui besarnya perubahan variabel terikat yang disebabkan oleh perubahan yang terjadi variabel bebas. Atau dapat mengetahui pengaruh masing-masing dari variabel bebas terhadap variabel terikat (dependen).

Tabel 10. Koefisien Regresi Berganda

\begin{tabular}{|c|c|c|c|c|c|c|}
\hline \multicolumn{7}{|c|}{ Coefficients $^{a}$} \\
\hline & \multirow{2}{*}{ Model } & \multicolumn{2}{|c|}{$\begin{array}{c}\text { Unstandardized } \\
\text { Coefficients }\end{array}$} & \multirow{2}{*}{$\begin{array}{c}\begin{array}{c}\text { Standardized } \\
\text { Coefficients }\end{array} \\
\text { Beta }\end{array}$} & \multirow[b]{2}{*}{$t$} & \multirow[b]{2}{*}{ Sig. } \\
\hline & & B & $\begin{array}{l}\text { Std. } \\
\text { Error }\end{array}$ & & & \\
\hline \multirow{3}{*}{1} & (Constant) & 113,04 & 4,791 & & 23,59 & 0.000 \\
\hline & Usia & 4,426 & 1,184 & 0,191 & 3,739 & 0.000 \\
\hline & Religiusitas & $-0,1$ & 0,02 & $-0,25$ & $-4,9$ & 0.000 \\
\hline
\end{tabular}

a. Dependent Variable: Keyakinan Etis

Sumber: Data primer diolah, Tahun 2019

\section{Uji Hipotesis (T-test)}

Uji hipotesis digunakan untuk mengetahui secara masing-masing pengaruh dari variabel independen terhadap variabel dependen. Uji hipotesis dapat dilakukan dengan melihat hasil dari olah data secara SPSS. Apabila nilai sig lebih kecil < daripada 0,05 atau nilai $t_{\text {hitung }}>t_{\text {tabel }}$ maka dapat dikatakan terdapat pengaruh variabel $\mathrm{X}$ terhadap variabel Y. Sebaliknya apabila nilai sig lebih besar $>$ daripada 0,05 atau nilai $t_{\text {hitung }}<\mathrm{t}_{\text {tabel }}$ maka dapat dikatakan tidak terdapat pengaruh antara variabel $\mathrm{X}$ terhadap variabel $\mathrm{Y}$. Uji t dalam penelitian ini dapat dijabarkan: 
Tabel 11. Hasil Pengujian Hipotesis Pertama (1)

\begin{tabular}{|c|c|c|c|c|c|c|}
\hline \multicolumn{7}{|c|}{ Coefficients $^{a}$} \\
\hline & \multirow{2}{*}{ Model } & \multicolumn{2}{|c|}{$\begin{array}{c}\text { Unstandardized } \\
\text { Coefficients }\end{array}$} & \multirow{2}{*}{$\begin{array}{c}\begin{array}{c}\text { Standardized } \\
\text { Coefficients }\end{array} \\
\text { Beta }\end{array}$} & \multirow[b]{2}{*}{$\mathrm{t}$} & \multirow{2}{*}{ sig. } \\
\hline & & B & $\begin{array}{l}\text { Std. } \\
\text { Error }\end{array}$ & & & \\
\hline \multirow{2}{*}{1} & (Constant) & 113,04 & 4,791 & & 23,594 & 0.000 \\
\hline & Usia & 4,426 & 1,184 & 0,191 & 3,739 & 0.000 \\
\hline
\end{tabular}

a. Dependent Variable: Keyakinan Etis

Sumber: Data primer diolah, Tahun 2019

Berdasarkan dari hasil pengolahan data secara SPSS pada tabel 4.16 diatas maka dapat diketahui nilai sig untuk variabel usia $\left(\mathrm{X}_{1}\right)$ sebesar 0,000 atau lebih kecil dari $<0,05$ sehingga dapat diambil kesimpulan bahwa terdapat pengaruh positif antara usia dengan keyakinan etis. Sedangkan jika dilihat dari nilai thitung diperoleh nilai thitung sebesar 3,739 atau lebih besar > dari $\mathrm{t}_{\text {tabel }}$ yakni 1,960 Maka dapat diartikan bahwa Hipotesis $\mathrm{H}_{1}$ dalam penelitian ini Diterima.

\section{Pengujian Hipotesis Kedua $\left(\mathrm{H}_{2}\right)$}

Pengujian hipotesis kedua dalam penelitian ini dilakukan untuk melihat pengaruh antara variabel independen religiusitas terhadap variabel dependen yakni keyakinan etis atau ethical beliefs. Dimana hasil dari pengujian hipotesis kedua dalam penelitian ini dapat dilihat pada tabel 12 sebagai berikut:

Tabel 12. Hasil Pengujian Hipotesis Kedua $\left(\mathbf{H}_{2}\right)$

\begin{tabular}{|c|c|c|c|c|c|c|}
\hline \multicolumn{7}{|c|}{ Coefficients $^{a}$} \\
\hline & \multirow{2}{*}{ Model } & \multicolumn{2}{|c|}{$\begin{array}{c}\text { Unstandardized } \\
\text { Coefficients }\end{array}$} & \multirow{2}{*}{$\begin{array}{c}\begin{array}{c}\text { Standardized } \\
\text { Coefficients }\end{array} \\
\text { Beta }\end{array}$} & \multirow[b]{2}{*}{$\mathrm{t}$} & \multirow[b]{2}{*}{ Sig. } \\
\hline & & B & $\begin{array}{l}\text { Std. } \\
\text { Error }\end{array}$ & & & \\
\hline \multirow{2}{*}{1} & (Constant) & 113,04 & 4,791 & & 23,594 & 0.000 \\
\hline & Religiusitas & $-0,1$ & 0,02 & $-0,25$ & $-4,9$ & 0.000 \\
\hline
\end{tabular}

Sumber: Data primer diolah, Tahun 2019

Berdasarkan data yang telah diperoleh dari hasil olah data dengan program SPSS Pada tabel 4.17 diatas, diketahui nilai sig untuk variabel religiusitas adalah sebesar 0,000 atau lebih kecil < dari 0,05, sehingga dapat diambil kesimpulan bahwa terdapat pengaruh antara variabel religiusitas $\left(\mathrm{X}_{2}\right)$ terhadap variabel keyakinan etis $(\mathrm{Y})$. Sedangkan untuk arah pengaruh dari variabel religiusitas sendiri berpengaruh kearah negatif dengan nilai koefisien beta $(\beta)$ yakni 0,100 sehingga dapat dambil kesimpulan bahwa Hipotesis kedua dalam penelitian ini Ditolak.

\section{Pengujian Hipotesis Ketiga $\left(\mathbf{H}_{3}\right)$}

Pengujian hipotesis ketiga (H3) dilakukan untuk mengetahui apakah terdapat perbedaan keyakinan etis (ethical beliefs) antara mahasiswa akuntansi tingkat awal dengan mahasiswa akuntansi yang berada pada tingkat akhir di universitas negeri maupun swasta yang ada di kota padang. Hasil dari penelitian hipotesis ketiga dalam penelitian ini dapat dilihat pada tabel 13 sebagai berikut: 
Tabel 13. Hasil Pengujian Hipotesis Ketiga $\left(\mathrm{H}_{3}\right)$

\begin{tabular}{ccccccc}
\hline & Tingkat & $\mathrm{N}$ & Mean & $\begin{array}{c}\text { Std. } \\
\text { Deviation }\end{array}$ & Sig. & $\mathrm{T}$ \\
\hline & Mahasiswa & & & & & \\
Ethical \\
$\begin{array}{c}\text { Beliefs } \\
(\mathrm{Y})\end{array}$ & $\begin{array}{c}\text { Tingkat } \\
\text { Akhir }\end{array}$ & 96 & 95.06 & 9.636 & & \\
\cline { 2 - 3 } & $\begin{array}{c}\text { Mahasiswa } \\
\text { Tingkat } \\
\text { Awal }\end{array}$ & 260 & 90.47 & 11.228 & & \\
\hline
\end{tabular}

Sumber: Data primer diolah, Tahun 2019

Berdasarkan dari hasil pengolahan data secara SPSS pada tabel 4.17 diatas maka dapat diketahui nilai $t_{\text {hitung }}$ sebesar 3,556 atau lebih lebih besar > dari nilai $t_{\text {tabel }}$ yakni 1,960. Sedangkan jika dilihat dari nilai sig diketahui nilai sig $(p)$ sebesar 0,000. Atau dapat dikatakan lebih kecil dari 0,05. Dengan persamaan sig. $(p)<$ sig. $\alpha(0,000<0,05)$, maka dapat diambil kesimpulan bahwa Hipotesis ketiga dalam penelitian ini diterima. Maka dapat diartikan bahwa terdapat perbedaan keyakinan etis yang signifikan antara mahasiswa tingkat awal dengan mahasiswa tingkat akhir.

\section{PEMBAHASAN}

\section{Usia Berpengaruh Signifikan Positif Terhadap Keyakinan Etis}

Dalam penelitian ini hipotesis pertama $\left(\mathrm{H}_{1}\right)$ yang digunakan yakni usia $\left(\mathrm{X}_{1}\right)$ berpengaruh signifikan positif terhadap keyakinan etis atau ethical beliefs (Y). Dimana dari hasi pengolahan data secara SPSS diperoleh nilai thitung $>$ dari tabel yakni 3,736 > 1,960 dan nilai sig yakni sebesar $(p)<$ Sig. $\alpha(0,000<0,05)$, maka dapat dikatakan hipotesis dalam penelitian ini Diterima. Hasil dari penelitian ini sejalan dengan penelitian yang dilakukan oleh Perryer, Catherine (2002) yang menemukan bahwa usia dan gender berpengaruh signifikan terhadap keyakinan etis, sedangkan faktor lain dari lingkungan kerja juga mempengaruhi dari keyakinan etis yang ada.

Hasil dari penelitian ini juga sejalan dengan penelitian yang dilakukan oleh Comunale et.al (200) yang melakukan penelitian dengan judul "Professional ethical crises : A Case study of accounting majors". Dimana hasil penelitian menunjukkan bahwa variabel usia berpengaruh signifikan terhadap persepsi mahasiswa akuntansi tentang krisis etika professional. Hasil penelitian ini membuktikan teori cognitive moral development yang dikembangkan oleh kolhberg (1969) dan telah dikembangkan pada penelitian selanjutnya yang dilakukan oleh Kohlberg, Lawrance (1973) dimana hasil penelitian menyatakan bahwa umur memiliki pengaruh pada pertimbangan etis seseorang dan berkembang melalui enam langkah-langkah progresif, dari level pre-conventional samai kepada level post-conventional, yang dimana semakin meningkatnya umur seseorang, maka semakin meningkat pula tingkatan level dan pemahaman seseorang tentang perilaku etis. Penelitian Thoma (1984) dalam Chan dan Leung (2006) juga menemukan bahwa sikap dan etika yang timbul dari dalam diri seseorang dapat dipengaruhi oleh usia seseorang. Maka dari itu usia seseorang juga menentukan sikap, tingkah laku maupun moral seseorang.

\section{Religiusitas Berpengaruh Signifikan Positif Terhadap Keyakinan Etis}

Hipotesis kedua dalam penelitian ini adalah religiusitas $\left(\mathrm{X}_{2}\right)$ berpengaruh signfikan positif terhadap keyakinan etis (ethical beliefs) (Y). Dimana dari hasil perhitungan dengan

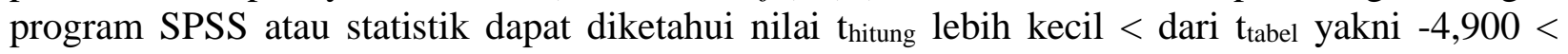


1,960 dengan nilai sig. $\alpha(0,000<0,05)$, maka dapat diambil kesimpulan bahwa religiusitas berpengaruh negatif terhadap keyakinan etis, sehingga dapat dikatakan bahwa hipotesis $\mathrm{H}_{2}$ Ditolak. Dikarenakan arah pengaruh dari religiusitas berpengaruh negatif.

Hasil dari penelitian tidak berhasil membuktikan konsep penelitian yang dilakukan oleh Peterson et al (2010) yang menunjukkan bahwa terdapat hubungan positif signifikan antara religiousity dengan etika bisnis. Hasil penelitian ini juga tidak sejalan dengan penelitian yang dilakukan oleh Julianto dan Kamayanti (2013) yang menemukan bahwa religiousity berpengaruh pada persepsi etis mahasiswa akuntansi. Hal ini dikarenakan religiusitas dianggap memiliki hubungan dengan perbaikan moral etis seseorang (Burks, 2006). Sedangkan hasil penelitian Burks (2006) juga menemukan bahwa pendidikan etis akan meningkatkan perilaku moral. Dalam perihal religiusitas, hubungan yang terkait dengan peningkatan moral menjadi perdebatan, sementara orang melihat bahwa perbaikan moral dan religiusitas sebagai hubungan yang terikat, namun ada beberapa yang menyatakan bahwa hubungan tersebut adalah yang terpisah. Mereka menanggap bahwa etika itu terpisah dari konsep religiusitas.

\section{Terdapat Perbedaan Ethical Beliefs Antara Mahasiswa S1 Akuntansi Tingkat Awal} Dengan Mahasiswa S1 Akuntansi Tingkat Akhir Di Kota Padang

Hipotesis ketiga $\left(\mathrm{H}_{3}\right)$ yang diajukan peneliti dalam penelitian ini yaitu terdapat perbedaan ethical beliefs antara mahasiswa akuntansi tingkat awal dengan mahasiswa akuntansi tingkat akhir. Dimana diketahui memiliki nilai $t_{\text {hitung }}>\mathrm{t}_{\text {tabel }}(3,556>1,960)$ dan nilai sig. $(p)<$ sig. $\alpha$ $(0,000<0,05)$, maka H5 diterima. Dapat disimpulkan bahwa terdapat perbedaan ethical beliefs mahasiswa akuntansi tingkat akhir dengan ethical beliefs mahasiswa akuntansi tingkat awal.

Penelitian ini mendukung penelitian yang dilakukan oleh Yulianti dan Fitriany (2005) menemukan bahwa mahasiswa akuntansi tingkat awal dan mahasiswa tingkat akhir berbeda dalam penilaian etis.Risa (2010) menyatakan bahwa mahasiswa tingkat akhir memiliki persepsi etis yang lebih baik dibandingkan dengan mahasiswa tingkat awal.

\section{KESIMPULAN DAN SARAN Kesimpulan}

Berdasarkan dari hasil pembahasan dan pengolahan data secara statistik maka dapat ditarik beberapa kesimpulan yang terdapat didalam penelitian ini diantaranya adalah sebagai berikut: Penelitian ini membuktikan konsep Peterson et.al (2001) yang mengatakan teori kognitif berpengaruh terhdap pengambilan keputusan dimana, variabel usia berpengaruh signifikan positf terhadap keyakinan etis.

Dalam penelitian ini juga menunjukkan bahwa terdapat pengaruh antara religiusitas dalam keyakinan etis, namun memiliki pengaruh kearah negatif, sebab hasil pengolahan data menunjukkan arah pengaruh atau $(\beta)$ bernilai minus. Hal ini tidak sesuai dengan penelitian sebelumnya yang dilakukan oleh Keller et.al (2007) yang menyatakan bahwa religiusitas merupakan faktor yang paling kuat sebagai dasar pengambilan keputusan akuntan.

\section{Saran}

Berdasarkan pembahasan dan kesimpulan di atas, maka penulis memberikan saran sebagai berikut: Penelitian selanjutnya dapat melakukan penelitian dengan menggunakan variabel yang lain dalam mengukur religiusitas, selain itu penelitian selanjutnya juga dapat mengubah subjek dan objek penelitian untuk dapat memberikan hasil yang berbeda dengan menambahkan variabel baru, untuk lebih dapat digeneralisir. 
Penelitian selanjutnya juga dapat menggabungkan teknik wawancara dan teknik kuesioner atau trianggulasi data, untuk dapat lebih menggambarkan hasil penelitian secara maksimal serta meminimalisasi kelemahan dari faktor internal serta dapat lebih meyakinkan peneliti terhadap hasil yang diperoleh.

\section{DAFTAR PUSTAKA}

Arikunto, S. (2009). Dasar-dasar Evaluasi pendidikan. Jakarta: Bumi Aksara.

Ali, Mohammad dan Mohammad Asrori. (2004). Psikologi Remaja (Perkembangan Peserta Didik). Jakarta: Bumi Aksara

Andi Mappiare. (1996). Pengantar Konseling dan Psikoterapi, Jakarta: Raja Grafindo

Agoes, Sukrisno, Ardana \& I Cenik. (2011). Etika Bisnis dan Profesi : Tantangan Membangun Manusia Seutuhnya. Jakarta: Salemba Empat.

Chung, J. and G. S. Monroe. (2003). A Research Note on The Effect of Gender and Task Complexity on Audit judgment. Journal of Behavioral Research,13, 111-125.

Coate and Frey. (2000). Some Evidence on the Ethical Disposition of Accounting Students : Context and Gender Implications. Teaching Business Ethis. 4(4), 379-404.

Dewanti, Diwi. (2015). Pengaruh Orientasi Etis dan Gender terhadap Persepsi Mahasiswa mengenai Perilaku Tidak Etis Akuntan (Studi Empiris Mahasiswa S1 Akuntansi Universitas Negeri Yogyakarta. Skripsi. Universitas Negeri Yogyakarta.

Dawson, L. M. (1995)."Women and men, morality and ethics". Business Horizons, 61-68.

Duska, Ronald F and Brenda Shay Duska. (2011). Accounting Ethics. United Kingdom: Blackwell Publishing. E-Book

Falah, Syaikhul. (2006). Pengaruh Budaya Etis Organisasi dan Orientasi Etika Terhadap Sensitivitas Etika (Studi Empiris Tentang Pemeriksaan Internal di Bawasda Pemda Рариа". Tesis Universitas Diponegoro. Semarang

Farisi, Salman Al. (2013). Pengaruh Lingkungan keluarga, Konsep Diri, dan Iklim Sosial terhadap Kemandirian Siswa SMKN 3 Yogyakarta. skripsi

Ghozali, Imam. (2005). Aplikasi Analisis Multivariat dengan Program SPSS. Semarang: Universitas Diponrgoro.

Hurlock, E.B. (1980). Perkembangan Anak Jilid 1 Edisi Keenam. Jakarta: Erlangga

Hurlock, E.B. (1993). Psikologi Perkembangan: Suatu pendekatan sepanjang rentang kehidupan (edisi kelima). Jakarta: Erlangga.

Hurlock, E.B. (2002). Psikologi Perkembangan. 5th edition. Erlanga: Jakarta.

Idris. (2010). Model Aplikasi Analisis Data Kuantitatif dengan Program SPSS Edisi Revisi III.UNP : Padang.

Jamilah et al. 2007. "Pengaruh Gender,Tekanan Ketaatan, DanKompleksitas Tugas Terhadap Audit Judgment." SNA X Makasar. 26-28 Juli.

KBBI Online. 2016. Kamus Besar Bahasa Indonesia [online] tersedia pada (www.pusatbahasa.diknas.go.id/kbbi). Diakses 24 Maret 2018.

Kenhove, Patrick Van., dkk. 2001."An Empirical Investigation of the Relationships between Ethical Beliefs, Ethical Ideology, Political Preference and Need for Closure. Jounal of Business Ethich: 347-361.

Kohlberg, Lawrence.1973. "The Claim to Moral Adequacy of a Highest Stage of Moral Judgment". Journal of Philosophy70: 630-646. 
Mochammad Mukti Ali, Ujang Sumarwan, Setiadi Djohar, Eva Z. Yusuf. 2014. "An Analyzed Model Of Consumer Perceived Value In Selecting Retail Shop For Fresh Product. ISSN 2304-0777.

Monks, F. J., dkk. 2006. Psikologi Perkembangan: Pengantar dalam Berbagai Bagiannya. Yogyakarta: Gajah Mada University Press.

Nugrahaningsih, P. 2005. Analisis Perbedaan Perilaku Etis Auditor di KAP dalam Etika Profesi(Studi Terhadap Peran Faktor-faktor Individual: Locus of Control, Lama Pengalaman Kerja,Gender dan Equity Sensitivity).SNAVIII Solo.p. 617-630.

Okleshen, M., \& Hoyt, R. (1996). A cross cultural comparison of ethical perspectives and decision approaches of business students: United States of America versus New Zealand. Journal of Business Ethics, 15(5), 537.

O'leary, C dan , D Cotter., 2000, "The Ehics of Final Year Accountancy Students: an International Comparison”, Managerial Auditing Journal.

Peterson, D., Rhoads, A., \& Vaught, B. C. (2001). Ethical beliefs of business professionals: A study of gender, age and external factors. Journal of Business Ethics (31), 225-232.

Stark, R., \& Glock, C. Y. (1974). American Piety: The Nature of Religious Commitment.California: University of California Press. 